\title{
PENGARUH KOMPENSASI, BUDAYA ORGANISASI, PENGEMBANGAN KARIR DAN KEPUASAN KERJA TERHADAP PRESTASI KERJA KARYAWAN
}

\section{Made Dwika Pradnyana ${ }^{1}$ I Gusti Made Suwandana ${ }^{2}$}

${ }^{1}$ Fakultas Ekonomi dan Bisnis Universitas Udayana (Unud), Bali, Indonesia email: dwikapradnyana@gmail.com

\begin{abstract}
ABSTRAK
Hotel Jhony Legian sebagai lokasi penelitian dengan jumlah responden sebanyak 58 orang karyawan dipilih menjadi sampel menggunakan teknik penentuan sampel jenuh. Pengumpulan data dilakukan melalui wawancara dan kuesioner. Hasl dari penelitian ini memberikan sebuah implikasi kepada hotel jhony mengenai pentingnya kompensasi, budaya organisasi, pengembangan karir dan kepuasan kerja dapat mempengaruhi prestasi kerja karyawan Hotel Jhony Legian. Adapun keterbatasan penelitian antara lain faktorfaktor yang mempengaruhi prestasi kerja karyawan dalam penelitian ini hanya terdiri dari kompensasi, budaya organisasi, pengembangan karir dan kepuasan kerja, sedangkan masih banyak factor lain yang mempengaruhi prestasi kerja karyawan. Adanya keterbatasan yang kedua karena penelitian ini menggunakan kuesioner, terkadang jawaban yang diberikan oleh responden tidak menunjukkan keadaan yang sebenarnya.

Kata Kunci :kompensasi, budaya organisasi, pengembangan karir dan kepuasan kerja
\end{abstract}

\begin{abstract}
Jhony Legian Hotel as a research location with 58 respondents selected as samples using saturated sample selection techniques. Data collection is done through interviews and questionnaires. The results of this study have implications for the hotel jhony regarding the importance of compensation, organizational culture, career development and job satisfaction can improve the work performance of Jhony Legian Hotel employees. Regarding the limitations of the study between other factors that affect the work performance of researchers in this study only consisted of compensation, organizational culture, career development and job satisfaction, while other factors that affect employee performance. There is a second limitation because this study uses a questionnaire, the answers given by respondents do not determine the truth.

Keywords: compensation, organizational culture, career development and job satisfaction
\end{abstract}




\section{PENDAHULUAN}

Dalam era globalisasi dan pasar bebas saat ini setiap perusahaan yang bergerak di bidang perhotelan dihadapkan pada situasi lingkungan bisnis yang semakin tidak pasti dan persaingan yang sangat ketat untuk menjadi yang terbaik dalam bisnisnya. Untuk menghadapi persaingan tersebut, perusahaan dituntut untuk meningkatkan kinerja perusahaan pada semua aspek sember daya manusia (Sukmawati, 2013). Peran sumber daya manusia sangat diperlukan untuk mengadopsi segala perubahan yang terjadi. Sumber daya manusia yang ada di perusahaan yang bergerak di bidang perhotelan harus selalu dikembangkan secara berkelanjutan guna meningkatkan kemampuan agar sesuai dengan tuntutan lingkungan bisnis. Selain itu, perusahaan-perusahaanjuga dituntut untuk memikirkan, merancang dan mengeksekusi resolusi baru agar dapat memenuhi tuntutan perkembangan zaman. Tujuannya adalah untuk mendapatkan peluang yang lebih baik untuk dapat menjadi market leader sesuai dengan tuntutan (Kotler dan Amstrong, 2014). Meningkatkan kualitas sumber daya manusia yang terlibat dalam proses bisnis perusahaan merupakan salah satu upaya yang ditempuh oleh para pelaku bisnis untuk memenuhi tuntutanperkembangan zaman dan memenangkan kompetisi pada pasar global. Banyaknya perusahaan yang mulai beroperasi dalam bidang yang sama membuat jumlah pesaing semakin banyak. Keunggulan bersaing dapat tercapai jika perusahaan memiliki sumber daya manusia yang berkualitas, kompeten dan memiliki prestasi yang tinggi.Setiap perusahaan pasti memerlukan sumber daya untuk mencapai tujuannya. Sumber daya manusia adalah harta atau aset paling berharga dan paling 
penting yang dimiliki oleh suatu organisasi, karena keberhasilan organisasi sangat ditentukan oleh manusia (Ardana dkk., 2013). Pendapat serupa juga dinyatakan oleh (Voon et al., 2014) bahwa karyawan merupakan aset paling penting bagi organisasi dan organisasi harus memiliki pemimpin yang mampu memimpin dan memotivasi karyawan untuk mencapai tujuan organisasi. Salah satu upaya yang dapat dilakukan oleh perusahaan ialah dengan cara memberdayakan setiap karyawan seoptimal mungkin, serta mempertahankan karyawan agar dapat mewujudkan setiap visi dan misi yang menjadi tujuan perusahaan Kabene et al. (2013).

Fenomena yang dapat dicontohkan mengenai pemberian kompensasi adalah gaji, tunjangan dan insentif yang berdampak terhadap kinerja yang dilakukan oleh karyawan. Apabila terpenuhi pemberian kompensasi, secara langsung memberikan pengaruh terhadap kinerja, jika kinerja membaik akan berpengaruh terhadap prestasi kerja karyawan. Lalu fenomena mengenai budaya organisasi adalah kebebasan mengemukakan pendapat. Apabila kebebasan mengemukakan pendapat telah diberikan maka secara langsung karyawan tidak takut untuk mengemukakan pendapat dan itu akan berpengaruh terhadap prestasi kerja karyawan. Selanjutnya fenomena mengenai pengembangan karir adalah pelatihan dan pengembangan diri yang berdampak terhadap kinerja. Jika perusahaan memberikan pelatihan dan pengembangan diri pada karyawan maka itu sangat berpengaruh terhadap kinerja dan prestasi kerja karyawan akan meningkat. Dan yang terakhir adanya fenomena kepuasan kerja yaitu pengawasan, rekan kerja dan promosi. Jika karyawan telah menemukan hal tersebut pada perusahaan maka 
kinerja karyawan akan meningkat dan itu berpengaruh terhadap prestasi kerja karyawan.

Salah satu tujuan orang bekerja adalah untukmengimplementasikan kompetensi yang dimilikinya secara maksimal, dan tujuan lainnya untukmendapatkan kompensasi karena manusia dikendalikan oleh keinginan untuk mendapatkan uangyang lebih banyak, peningkatan karir, dan kekuasaan. Menurut Handoko, suatu cara untuk meningkatkan prestasi kerja karyawan adalah dengan memberikan kompensasi. Kompensasi merupakan salah satu cara yang dapat diberikan perusahaan berupa imbalan kepada karyawan. Kompensasi dapat meningkatkan ataupun menurunkan kinerjakaryawan. Pemberian kompensasi kepada karyawan perlu mendapatkanperhatian lebih oleh perusahaan. Kompensasi harus memiliki dasar yang kuat, benar dan adil. Apabila kompensasi dirasakan tidak adil maka akan menimbulkan rasa kecewa kepada karyawan, sehingga karyawan yang baik akan meninggalkan perusahaan. Oleh karena itu agar dapat mempertahankan karyawan yang baik, maka program kompensasi dibuat sedemikian rupa, sehingga karyawan yang berpotensi akan merasa dihargai dan bersedia untuk bertahan di perusahaan (Muljani, 2013). Oleh karena itu perhatian organisasi atau perusahaan terhadap pengaturan kompensasi secara rasional dan adil sangat diperlukan. Bila karyawan memandang pemberian kompensasi tidak memadai maka prestasi kerja, motivasi maupun kepuasan kerja mereka cenderung akan menurun. Kompensasi merupakan faktor yang mempengaruhi bagaimana dan mengapa orang-orang bekerja pada suatu organisasi. Para pegawai akan sangat termotivasi untuk bekerja keras jika 
I Made Dwika Pradnyana, Pengaruh Kompensasi,Budaya...

organisasi memberikan kompensasi dengan baik dan lancar sesuai dengan pekerjaan yang mereka lakukan.

Budaya organisasi menjadi salah satu faktor yang mempengaruhi prestasi kerja. Sebab budaya organisasi dibangun dari keyakinan terhadap nilai-nilai organisasi yang dapat digunakan untuk menggerakkan seluruh anggota organisasi dalam mewujudkan tujuanorganisasi. Menurut McShane dan Von Glinow (2015), budaya organisasi merupakan pola dasar dari nilai dan asumsi organisasi yang mengarahkan karyawan dalam organisasi untuk berpikir dan bertindak terhadap masalah dan kesempatan. Robbins (2013) menjelaskan bahwa organisasi yang memiliki budaya yang kuat dapat mempunyai pengaruh yang bermakna bagi perilaku dan sikap anggotanya.Di samping budaya organisasi sebagai salah satu cara atasan untuk meningkatkan produktivitas kerja pegawai juga dapat ditentukan oleh disiplin kerja karena disiplin kerja memiliki arti yang sangat penting bagi kelangsungan hidup organisasi, sebab dengan tingkat disiplin kerja yang tinggi organisasi dapat mencapai sasaran dan tujuan yang diinginkan dengan efektif dan efisien. Menurut Hasibuan (2013) menyatakan bahwa disiplin kerja adalah kesadaran dan kesediaan seorang pegawai untuk menaati semua peraturan dan norma-norma sosial yang berlaku.

Mengingat begitu pentingnya peran karyawan dalam suatu perusahaan, maka kegiatan pengembangan karier karyawan merupakan hal penting dalam upaya peningkatan prestasi kerja karyawan,misalnya melalui pendidikan karier, informasi karier, dan bimbingan karier.Setelah berbagai informasi dan bimbingan karier diberikan, kemudian penetapan karier merupakan langkah 
awal untuk jenjang karier seseorang, sehingga saat ini perlu adanya pengembangan karier masing-masing karyawan sesuai kemampuan dan keterampilan yang dimilikinya (Martoyo, 2015). Program pengembangan karier sangat penting dilakukan karena untuk menyesuaiakan antara kebutuhan dan tujuan karyawan dengan kesempatan karier yang tersedia di perusahaan saat ini maupun di masa mendatang. Permadi (2017) mengemukakan bahwa kepuasan kerja (jobstatification) adalah wujud dari persepsi pegawai yang tercermin dalam sikap danfokus pada perilaku pekerjaan. Ini juga merupakan suatu bentuk interaksi antara manusia dengan lingkungan pekerjaannya, Selain itu dalam bekerja ditunjukkan dengan adanya gairah dan semangat kerja, disiplin dan sebagainya. Sakirui et al. (2013) berpendapat bahwa dengan terciptanya kepuasan kerja dalam suatu perusahaan akan berdampak pada meningkatnya gairah kerja. Kepuasan kerja yang tinggi akan menandakan bahwa organisasi telah dikelola dengan baik dandengan manajemen yang efektif. Rae (2013) dalam penelitiannya mengatakan kepuasan kerja adalah bagian penting dari pengalaman hidup pegawai dalam bekerja, artinya terkait dengan seorang pegawai menerima cukup imbalan mendorong pegawai untuk tetap ditempat kerja mereka dan terus menghabiskan sebagian besar waktu untuk pemenuhan tugasnya. Aydogdu dan Asikgil (2013) dalam penelitiannya menyatakan bahwa semakin tinggi kepuasan kerja maka komitmen organisasional akan semakin meningkat pula. Kesuma (2016) penelitiannya menyatakan untuk meningkatkan komitmen pegawai dalam penerapan gaya kepemimpinan transformasional harus meningkatkan kepuasan kerja dulu sehingga dapat meningkatkan komitmen organisasi 
I Made Dwika Pradnyana, Pengaruh Kompensasi,Budaya...

Pengembangan karier merupakan proses peningkatan kemampuan kerja seseorang yang mendorong adanya peningkatan prestasi kerja dalam rangka mencapai karier yang diinginkan.Kegiatan pengembangan karier yang didukung oleh perusahaan, maka perusahaan mengharapkan adanya umpan balik dari karyawan yaitu berupa prestasi kerja. Prestasi kerja merupakan sebuah hasil kerja yang dicapai seorang karyawan sesuai dengan standar perusahaan. Prestasi kerja akan menambah manfaat baik dari pihak perusahaan maupun karyawan. Salah satu manfaatnya bagi karyawan yaitu dapat menambah pengalaman kariernya selama bekerja, sedangkan manfaatnya bagi perusahaan yaitu memudahkan untuk pengambilan keputusan (Wahyuni, 2014).

Masalah yang ada pada setiap masing-masing variabel antara lain pada variabel kompensasi adalah masalah pemberian upah dan gaji, pemberian tunjangan antara lain asuransi kesehatan, program pensiun dan tunjangan lainnya yang berkaitan dengan hubungan kepegawaian. Pada variabel budaya organisasi terdapat masalah sebagai berikut mudahnya terbentuk kelompok-kelompok yang bertentangan satu sama lain, kesetiaan kepada kelompok melebihi kesetiaan kepada organisasi, anggota organisasi tidak segan-segan mengorbankan kepentingan organisasi untuk kepentingan kelompok atau diri sendiri. Pada variabel pengembangan karir terdapat masalah sebagai berikut menurunnya kemampuan organisasi untuk memperoleh dan mempertahankan karyawan yang berkualitas, menurunnya motivasi antar karyawan. Pada variabel kepuasan kerja memiliki masalah sebagai berikut kurangnya perhatian yang diberikan oleh pemimpin terhadap pekerjaan yang dilakukan oleh bawahan, kurangnya 
kesempatan bagi bawahan yang bertujuan untuk meningkatkan motivasi bawahan untuk dapat maju dan berkembang dalam organisasi. Dan yang terakhir masalah yang ada dalam variabel prestasi kerja karyawan kurangnya ketepatan, ketelitian, keterampilan dan keberhasilan karyawan dalam melaksanakan pekerjaan.

Berdasarkan hasil wawancara dan observasi dengan kepala HRD dan pada 10 pegawai hotel Jhonny bahwa terdapat permasalahan yang berindikasi menimbulkan rendahnya prestasi kerja. Untuk meningkatkan prestasi kerja karyawan, perusahaan perlu memperhatikan faktor-faktor yangmempengaruhi prestasi kerja tersebut. Prestasi kerja merupakan cerminan keberhasilan perusahaan dalam mengelola kebutuhan karyawan (Hasibuan, 2015). Menurut Hamdani (2013), faktor-faktor yang mempengaruhi prestasi kerja di antaranya adalah budaya organisasi, iklim organisasi dan komitmen organisasi. Selain itu, Martoyo (dalam Reffiany, 2014) juga menyatakan bahwa prestasi kerja dipengaruhi oleh kepuasan kerja, motivasi, tingkat stres, kondisi fisik pekerjaan, sistem kompensasi, aspek-aspek ekonomi, aspek-aspek teknis dan perilaku lainnya. Lalu berdasarkan hasil observasi menemukan bahwa permasalahan terhadap prestasi kerja karyawan yang ditemukan adalah masih adanya pegawai yang belum memiliki kualitas kerja meliputi ketepatan dan ketelitian karyawan dalam melaksanakan pekerjaannya dan keandalan yaitu meliputi kemampuan karyawan dalam mengikuti intruksi atau perintah, berinisiatif sikap kehati-hatian dan kerajinan pada Hotel Jhony Legian.

Berdasarkan teori pertukaran sosial (social exchange theory), karyawan akan menukar usaha mereka dengan perjanjian penghargaan di masa depan (Blau, 
1964 dalam Korir, 2016). Definisi kompensasi adalah jumlah keseluruhan yang ditetapkan sebagai pengganti jasa yang telah dikeluarlan oleh tenaga kerja meliputi masa atau syarat-syarat tertentu (Hadi Poerwono, 2014). Teori ini semula dikembangkan oleh Thibaut dan Kelley pada tahun 1959. Teori pertukaran sosial menunjukkan bahwa karyawan yang menghargai benefit yang diterima dari organisasinya, seperti gaji, tunjangan atau kondisi kerja, akan melakukan timbal balik dengansikap kerja yang positif. Teori tersebut mengemukakan bahwa individu membentuk hubungan pertukaran sosial sejauh mereka memperoleh benefit yang bermanfaat dan bahwa manfaat ini diberikan secara adil (Cropanzano, 2013 \& Haar, 2013). Alasan saya menggunakan teori pertukaran sosial karena teori ini berpandangan dengan kompensasi, budaya organisasi, pengembangan karir dan kepuasan kerja yang menyangkut dengan prestasi kerja karyawan. Dan menurut teori ini karyawan akan menukar usaha mereka dengan perjanjian penghargaan dimasa depan dan jika itu terjadi maka karyawan yang puas dengan kompensasi cenderung memiliki prestasi kerja atau kinerja pekerjaan yang lebih tinggi, komitmen organisasional dan niat turnover yang lebih lemah.

Kompensasi adalah semua pendapatan yang diterima karyawan yang berbentuk uang, barang langsung atau tidak langsung yang merupakan bentuk biaya yang harus dikeluarkan perusahaan dengan harapan memperoleh imbalan berupa prestasi kerja dari karyawan (Hasibuan, 2013 \& Sofyandi, 2013). Menurut Garry Dessler (2014) definisi kompensasi adalah semua bentuk penggajian atau ganjaran yang mengalir kepada pegawai dan timbul dari kepegawaiannya.Sedangkan menurut Susilo Martoyo (2015), kompensasi 
didefinisikan sebagai pengaturan keseluruhan pemberian balas jasa bagi “employers” maupun "employees” baik yang langsung berupa uang (financial) maupun yang tidak langsung berupa uang (nonfinancial). Dari definisi tersebut dapat disadari bahwa suatu kompensasi jelas akan dapat meningkatkan komitmen karyawan. Oleh karenanya penting sekali perhatian organisasi terhadap pengaturan kompensasi secara benar dan adil lebih dipertajam.

Penelitian yang dilakukan oleh Ratna (2014) Pengaruh Kepemimpinan Dan Kompensasi Terhadap Prestasi Kerja Karyawan PT. Pelindo III Cabang Semarang menunjukkan hasil bahwa kompensasi berpengaruh positif terhadap prestasi kerja karyawan. Setiawan (2016) melakukan penelitian yang berjudul Pengaruh Motivasi Kerja Dan Kompensasi TerhadapPrestasi Kerja Karyawan Pt Sun Star MotorCabang Negara Tahun 2016 yang menunjukkan hasil bahwa kompensasi berpengaruh signifikanterhadap prestasi kerja karyawan. Semakin baik kompensasi maka semakin baik pula prestasi kerja karyawan. Penelitian yang dilakukan oleh Susi (2016) Pengaruh Kompensasi Terhadap Prestasi Kerja Karyawan pada Hotel ASEAN Pekan Baru menunjukkan hasil bahwa kompensasi berpengaruh positif terhadap prestasi kerja karyawan. Penelitian yang dilakukan oleh Tri Darmawati (2016) Pengaruh Kompensasi Terhadap Prestasi Kerja Karyawan Pegawai Pada Fakultas Ekonomi Universitas PGRI Palembang menunjukkan hasil bahwa kompensasi berpengaruh positif terhadap prestasi kerja karyawan. Penelitian yang dilakukan oleh Nel Arianty (2015) Pengaruh Kompensasi Terhadap Prestasi Kerja Karyawan pada PT. Asam Jawa Medan 
I Made Dwika Pradnyana, Pengaruh Kompensasi,Budaya...

menunjukkan hasil bahwa kompensasi berpengaruh positif terhadap prestasi kerja karyawan.

Berdasarkan dari penelitian-penelitian diatas, maka dapat diajukan hipotesis sebagai berikut :

$\mathrm{H}_{1}$ : Kompensasi berpengaruh positif terhadap prestasi kerja karyawan.

Penelitian yang dilakukan oleh Putra (2013) Pengaruh Budaya Perusahaan Terhadap Prestasi Kerja Karyawan PT. Pembangkitan Jawa- Bali Surabaya Unit Pelayanan Pemeliharaan menunjukkan hasil bahwa terdapat pengaruh yang signifikan variabel budaya perusahaan terhadap prestasi kerja karyawan. Hal ini dapat dipahami bahwa dengan budaya perusahaan yang semakin baik berarti akan mampu meningkatkan prestasi kerja karyawan, namun jika budaya perusahaan yang diterapkan PT Pembangkitan JawaBali Surabaya kurang baik, maka akan sulit untuk meningkatkan prestasi kerja karyawan PT Pembangkitan Jawa-Bali Surabaya unit pelayanan pemeliharaan.Mamuaja (2016) melakukan penelitian yang berjudul Pengaruh Budaya Organisasi, Lingkungan Kerja Dan Disiplin Kerja Terhadap Prestasi Kerja Karyawan PT. Daya Anugrah Mandiri Cabang Airmadidi menghasilkan bahwa budaya organisasi berpengaruh terhadap prestasi kerja karyawan dengan nilai koefisien yang signifikan. Hal ini mengindikasikan bahwa budaya organisasi merupakan salah satu variabel penting atau prediktor dari prestasi kerja karyawan. Penelitian yang dilakukan oleh Shinta (2016) Pengaruh Budaya Perusahaan Terhadap Prestasi Kerja Karyawan Outsourcing Pada PT. Pipa Mas Batam menunjukkan hasil bahwa terdapat pengaruh yang signifikan variabel budaya perusahaan terhadap prestasi kerja karyawan.Penelitian yang 
dilakukan oleh Moh. Fanani (2015) Pengaruh Budaya Perusahaan Terhadap Prestasi Kerja Karyawan Pada PT. PJTKI Lentera Bunga Bangsa Sejati Surakarta menunjukkan hasil bahwa terdapat pengaruh yang signifikan variabel budaya perusahaan terhadap prestasi kerja karyawan.Penelitian yang dilakukan oleh Riyan Putra (2013) Pengaruh Budaya Perusahaan Terhadap Prestasi Kerja Karyawan PT Pembangkitan Jawa-Bali-Surabaya Unit Pelayanan Pemeliharaan menunjukkan hasil bahwa terdapat pengaruh yang signifikan variabel budaya perusahaan terhadap prestasi kerja karyawan. Berdasarkan dari penelitianpenelitian diatas, maka dapat diajukan hipotesis sebagai berikut :

$\mathrm{H}_{2}$ : Budaya Organisasi berpengaruh positif terhadap prestasi kerja karyawan.

Penelitian yang dilakukan oleh Salama (2017)yang berjudul Pengaruh Pelatihan, Motivasi Kerjadan PengembanganKarir Terhadap Prestasi Kerja Pegawai Pada SatuanPolisi Pamong PrajaKabupaten Soppengmenunjukkan hasil bahwapengembangan karir berpengaruh positif dan signifikan terhadap prestasi kerjapegawai pada Satuan Polisi Pamong Praja Kabupaten Soppeng Nurhasanah (2017) melakukan penelitian yang berjudul Pengaruh Pengembangan Karir Terhadap Prestasi Kerja Karyawan pada Bank BJB Syariah Kantor Cabang Braga mendapatkan hasil bahwa Pengembangan karir berpengaruh positif dan signifikan terhadap prestasi kerja pegawai. Hal ini dapat diartikan bahwa jika pengembangan karir yang diberikan Bank BJB Syariah KC Braga baik maka akan memberikan dampak positif terhadap prestasi kerja karyawan.Penelitian yang dilakukan oleh Luvy Chintya (2017) Pengaruh Pengembangan Karir Terhadap Prestasi Kerja Karyawan Pada PT. Marindo Utama Penata Kawasan Bandung 
I Made Dwika Pradnyana, Pengaruh Kompensasi,Budaya...

mendapatkan hasil bahwa Pengembangankarir berpengaruh positif dan signifikan terhadap prestasi kerja pegawai.Penelitian yang dilakukan oleh Harjanti (2017) dengan judul Pengaruh Pengembangan Karir Terhadap Prestasi Kerja Karyawan Pada PT. Pos Indonesia Cabang Tasikmalaya mendapatkan hasil bahwa Pengembangankarir berpengaruh positif dan signifikan terhadap prestasi kerja pegawai.Penelitian yang dilakukan oleh Deawati (2015) Pengaruh Pengembangan Karir Terhadap Prestasi Kerja Pegawai Pada Bidang Pendidikan Non Formal Dinas Pendidikan Kabupaten Majalenka mendapatkan hasil bahwa Pengembangan karir berpengaruh positif dan signifikan terhadap prestasi kerja pegawai.

$\mathrm{H}_{3}$ : Pengembangan karir berpengaruh positif terhadap prestasi kerja karyawan.

Penelitian yang dilakukan oleh Rina (2017) dengan judul Pengaruh Kepuasan Kerja Terhadap Prestasi Kerja Karyawan pada CV. Organik Agro System di Bandar Lampung mendapatkan hasil bahwa kepuasan kerja berpengaruh positif dan signifikan terhadap prestasi kerja pegawai.Penelitian yang dilakukan oleh Charitin Devi (2017) Pengaruh Kepuasan Kerja Terhadap Prestasi Kerja Pegawai Pada Dinas Tenaga Kerja dan Transmigrasi Kabupaten Musi Banyuasin mendapatkan hasil bahwa kepuasan kerja berpengaruh positif dan signifikan terhadap prestasi kerja pegawai.Penelitian yang dilakukan oleh Ilham Anshari (2013) dengan judul Pengaruh Kepuasan Kerja Terhadap Prestasi Kerja Karyawan pada PT. Bank Rakyat Indonesia Cabang Binjai mendapatkan hasil bahwa kepuasan kerja berpengaruh positif dan signifikan terhadap prestasi kerja pegawai.Penelitian yang dilakukan oleh Agil Winedhar (2016) 
dengan judul Kepuasan Kerja Terhadap Prestasi Kerja Karyawan (Studi Dalam Divisi Account Officer Bank Rakyat Indonesia Cabang Malang Kawi) mendapatkan hasil bahwa kepuasan kerja berpengaruh positif dan signifikan terhadap prestasi kerja pegawai.Penelitian yang dilakukan oleh Supriyanto (2016) dengan judul Kepuasan Kerja Terhadap Prestasi Kerja Karyawan pada Rumah Sakit Islam Malang mendapatkan hasil bahwa kepuasan kerja berpengaruh positif dan signifikan terhadap prestasi kerja pegawai.

$\mathrm{H}_{4}$ : Kepuasan Kerja berpengaruh positif terhadap prestasi kerja karyawan.

\section{METODE PENELITIAN}

Lokasi penelitian ini adalah Hotel Jhony Legian yang berlokasi di Jl. Nakula Timur, Legian Kaja, Kuta, Kabupaten Badung, Bali.Objek penelitian ini adalah Kompensasi, Budaya Organisasi, Pengembangan Karir dan Kepuasan Kerja Terhadap Prestasi Kerja Karyawan.

Populasi dalam penelitian ini adalah seluruh karyawan kecuali manager pada Hotel Jhony, Legian Badung yang berjumlah 58 orang dengan menggunakan 5475ariab sampling jenuh atau sensus.

Model analisis yang digunakan untuk menyelesaikan permasalahan penelitian ini adalah regresi linier berganda yang merupakan suatu prosedur variable dalam menganalisis pengaruh variable bebas $\left(\mathrm{X}_{1}, \mathrm{X}_{2}, \mathrm{X}_{3}, \mathrm{X}_{4}\right)$ terhadap variable terikat (Y) dengan persamaan sebagai berikut:

$$
\mathrm{Y}=\mathrm{a}+\mathrm{b}_{1} \mathrm{X}_{1}+\mathrm{b}_{2} \mathrm{X}_{2}+\mathrm{b}_{3} \mathrm{X}_{3}+\mathrm{b}_{4} \mathrm{X}_{4}+\mathrm{ei}
$$


Keterangan :

$\begin{array}{lll}\mathrm{Y} & = & \text { Prestasi Kerja Karyawan } \\ \mathrm{X}_{1} & = & \text { Kompensasi } \\ \mathrm{X}_{2} & = & \text { Budaya Organisasi } \\ \mathrm{X}_{3} & = & \text { Pengembangan Karir } \\ \mathrm{X}_{4} & = & \text { Kepuasan Kerja } \\ \mathrm{a} & = & \text { Bilangan Konstanta dari persamaan regresi } \\ \mathrm{b}_{1}, \mathrm{~b}_{2}, \mathrm{~b}_{3}, \mathrm{~b}_{4} & = & \text { Koefisien regresi variabel } \mathrm{X}_{1}-\mathrm{X}_{2}\end{array}$

\section{HASIL DAN PEMBAHASAN}

Berdasarkan hasil penelitian yang dilakukan, telah diketahui karakteristik responden meliputi jenis kelamin, usia, lama bekerja, dan tingkat pendidikan terakhir. Data mengenai karakteristik responden disajikan pada Tabel 1 berikut ini.

Tabel 1.

Karakteristik Responden Penelitian

\begin{tabular}{|c|c|c|c|c|}
\hline No. & Kriteria & Klasifikasi & Jumlah (Orang) & $\begin{array}{c}\text { Persentase } \\
(\%)\end{array}$ \\
\hline \multirow[t]{3}{*}{1.} & Jenis Kelamin & Pria & 33 & 56,9 \\
\hline & & Wanita & 25 & 43,1 \\
\hline & Jumlal & & 58 & 100 \\
\hline \multirow[t]{6}{*}{2.} & Usia & 18-20 tahun & 2 & 3,4 \\
\hline & & 21-25 tahun & 18 & 31,0 \\
\hline & & 26-30 tahun & 20 & 34,5 \\
\hline & & 31-35 tahun & 14 & 24,1 \\
\hline & & 36-40 tahun & 4 & 6,9 \\
\hline & Jumlal & & 58 & 100 \\
\hline \multirow[t]{3}{*}{3.} & Lama Bekerja & $<1$ tahun & 26 & 44,8 \\
\hline & & $1-5$ tahun & 32 & 55,2 \\
\hline & Jumlah & & 58 & 100 \\
\hline \multirow[t]{7}{*}{4.} & Pendidikan & SMA/SMK & 29 & 50,0 \\
\hline & Terakhir & D1 & 5 & 8,6 \\
\hline & & D2 & 3 & 5,2 \\
\hline & & D3 & 10 & 17,2 \\
\hline & & D4 & 6 & 10,3 \\
\hline & & $\mathrm{S} 1$ & 5 & 8,6 \\
\hline & \multicolumn{2}{|c|}{ Jumlah } & 58 & 100 \\
\hline
\end{tabular}

Sumber: Data diolah, 2018

Tabel 1. menunjukkan hasil sebaran data karakteristik responden pada penelitian ini. Hasil menunjukkan bahwa sebagian besar responden berjenis 
kelamin pria dengan persentase sebesar 56,9\% dibanding responden wanita sebesar 43,1\%. Hal ini dapat berarti sebagian besar pekerjaan di Hotel Jhony Legianmembutuhkan tenaga pria untuk menyelesaikannya. Kelompok usia responden yang mendominasi adalah usia produktif dengan rentang usia terbanyak yakni 26-30 tahun yang memperoleh persentase sebesar 34,5\%. Berdasarkan lama bekerja, responden yang bekerja dengan rentang waktu 1 hingga 5 tahun mendominasi sebaran data dengan persentase sebesar 55,2\%. Sementara itu, responden dengan pendidikan terakhir SMA/SMK mendapatkan persentase terbanyak dibandingkan tingkat pendidikan yang lain yaitu sebesar 50\%. Hal ini dapat berarti bahwa para karyawan Hotel Jhony Legian sebagian besar tidak menempuh pendidikan tinggi.

Hasil analisis regresi linear berganda yang telah dilakukan, disajikan pada Tabel 2. berikut ini.

Tabel 2.

Hasil Analisis Regresi Linear Berganda

\begin{tabular}{lccc}
\hline \multicolumn{1}{c}{ Variabel } & $\begin{array}{c}\text { Koefisien Regresi } \\
\text { (B) }\end{array}$ & t hitung & Signifikansi t \\
\hline (Constant) & 20,021 & 17,325 & 0,000 \\
Kompensasi(X1) & 0,159 & 2,799 & 0,007 \\
Budaya Organisasi (X2) & 0,155 & 2,738 & 0,008 \\
Pengembangan Karir(X3) & 0,133 & 3,205 & 0,002 \\
Kepuasan Kerja(X4) & 0,165 & 3,021 & 0,003 \\
$\quad$ R=0,704 & & & \\
RSquare=0,596 & & & \\
$\quad$ Adjusted RSquare=0,558 & & &
\end{tabular}

Berdasarkan hasil analisis regresi linear berganda pada Tabel 2, diperoleh persamaan regresi sebagai berikut:

$$
\mathrm{Y}=0,159 \mathrm{X}_{1}+0,155 \mathrm{X}_{2}+0,133 \mathrm{X}_{3}+0,165 \mathrm{X}_{4}+\mathrm{e}
$$


Persamaan regresi linear berganda di atas menunjukkan arah masing-masing variabel bebas terhadap variabel terikatnya. Persamaan regresi linear berganda tersebut dapat diuraikan sebagai berikut. $\mathrm{X}_{1}=+0,159$, menunjukan bahwa kompensasi $\left(\mathrm{X}_{1}\right)$ berpengaruh positif terhadap prestasi kerja karyawan $(\mathrm{Y}) \mathrm{di}$ Hotel Jhony Legian, $\mathrm{X}_{2}=+0,155$, menunjukan bahwa budaya organisasi $\left(\mathrm{X}_{2}\right)$ berpengaruh positif terhadap prestasi kerja karyawan (Y) di Hotel Jhony Legian, $\mathrm{X}_{3}=+0,133$, menunjukan bahwa pengembangan karir $\left(\mathrm{X}_{3}\right)$ berpengaruh positif terhadap prestasi kerja karyawan $(\mathrm{Y})$ di Hotel Jhony Legian, $\mathrm{X}_{4}=+0,165$, menunjukan bahwa kepuasan kerja $\left(\mathrm{X}_{4}\right)$ berpengaruh positif terhadap prestasi kerja karyawan (Y) di Hotel Jhony Legian.

Pengujian hipotesis secara simultan (uji F) dilakukan untuk mengetahui pengaruh variabel-variabel bebas secara bersama-sama atau simultan atas suatu variabel terikat. Ketentuan angka probabilitas yang baik untuk digunakan sebagai model regresi harus $<0,05$. Jika nilai signifikansi kurang dari 0,05 , maka variabel bebas berpengaruh secara simultan terhadap variabel terikat.Hasil uji $\mathrm{F}$ ditunjukkan pada Tabel 3.

Tabel 3.

Hasil Uji F

\begin{tabular}{cccccc}
\hline Model & Sum of Squares & Df & Mean Square & F & Sig. \\
\hline Regression & 31,703 & 4 & 7,926 & 13,034 & 0,000 \\
Residual & 32,228 & 53 & 0,608 & & \\
Total & 63,931 & 57 & & & \\
\hline
\end{tabular}

Sumber:Data diolah, 2018

Berdasarkan hasil uji, nilai signifikansi $\mathrm{F}$ adalah sebesar 0,000 yang lebih kecil dari 0,05 $(\mathrm{F}<\alpha)$ yang berarti variabel bebasyaitu kompensasi $\left(\mathrm{X}_{1}\right)$, budaya organisasi $\left(\mathrm{X}_{2}\right)$, pengembangan karir $\left(\mathrm{X}_{3}\right)$, dan kepuasan kerja $\left(\mathrm{X}_{4}\right)$ berpengaruh signifikan secara serempak atau bersama-sama terhadap variabel terikat yaitu 
prestasi kerja karyawan (Y) di Hotel Jhony Legian, sehingga penelitian ini dapat dikatakan memenuhi uji kelayakan model atau model penelitian dinyatakan layak digunakan sebagai model regresi.

Koefisien determinasi digunakan untuk mengetahui tingkat korelasi antara kompensasi, budaya organisasi, pengembangan karir, dan kepuasan kerja dengan prestasi kerja karyawan. Hasil perhitungan koefisien determinasi ditunjukkan pada Tabel 2 yaitu angka R Square $\left(\mathrm{R}^{2}\right)$. Koefisien determinasi (R Square) sebesar 0,596 memiliki arti bahwa sebesar 59,6\% variasi kepuasan kerja karyawan di Hotel Jhony Legian dipengaruhi oleh kompensasi, budaya organisasi, pengembangan karir, dan kepuasan kerja, sedangkan sisanya sebesar 40,4\% dipengaruhi oleh faktor lain yang tidak dimasukkan ke dalam model penelitian.

Berdasarkan hasil analisis pengaruh budaya organisasi terhadap prestasi kerja karyawan, diperoleh nilai koefisien beta sebesar 0,155 yang berarti adanya arah yang positif serta nilai signifikansi sebesar 0,008 yang lebih kecil dari 0,05 berarti adanya pengaruh yang signifikan. Hasil ini mengindikasikan bahwa $\mathrm{H}_{0}$ ditolak dan $\mathrm{H}_{2}$ diterima sehingga budaya organisasi berpengaruh positif dan signifikan terhadap prestasi kerja karyawan.

Berdasarkan hasil analisis pengaruh pengembangan karirterhadap prestasi kerja karyawan, diperoleh nilai koefisien beta sebesar 0,133 yang berarti adanya arah yang positif serta nilai signifikansi sebesar 0,002 yang lebih kecil dari 0,05 berarti adanya pengaruh yang signifikan. Hasil ini mengindikasikan bahwa $\mathrm{H}_{0}$ ditolak dan $\mathrm{H}_{3}$ diterima sehingga pengembangan karirberpengaruh positif dan signifikan terhadap prestasi kerja karyawan. 
Berdasarkan hasil analisis pengaruh kepuasan kerja terhadap prestasi kerja karyawan, diperoleh nilai koefisien beta sebesar 0,165 yang berarti adanya arah yang positif serta nilai signifikansi sebesar 0,003 yang lebih kecil dari 0,05 berartiadanya pengaruh yang signifikan. Hasil ini mengindikasikan bahwa $\mathrm{H}_{0}$ ditolak dan $\mathrm{H}_{4}$ diterima sehingga kepuasan kerja berpengaruh positif dan signifikan terhadap prestasi kerja karyawan.

Berdasarkan hasil pengujian hipotesis pertama, diperoleh nilai koefisien beta sebesar 0,159 dengan signifikansisebesar 0,007. Nilai koefisien beta yang memiliki arah positif serta nilai signifikansi yang lebih kecil dari tingkat probabilitas 0,05 mengartikan bahwa $\mathrm{H}_{1}$ diterima. Hasil dari pengujian ini adalah kompensasi berpengaruh positif dan signifikan terhadap prestasi kerja karyawan. Artinya, apabila kompensasi yang diberikan perusahaan kepada para karyawan Hotel Jhony Legianberada dalam tingkat yang baik, maka prestasi kerja karyawan akan semakin meningkat. Sebaliknya, jika kompensasi dinilai tidak baik maka prestasi kerja karyawan akan semakin menurun.

Hasil penelitian ini memperkuat beberapa penelitian sebelumnya yang telah membuktikan bahwa kompensasi berpengaruh positif dan signifikan terhadap prestasi kerja karyawanseperti yang dilakukan Setiawan (2016) yang menyimpulkan bahwasemakin baik kompensasi maka semakin baik pula prestasi kerja karyawan. Begitu juga penelitian yang dilakukan Ratna (2014), Susi (2011), Tri Darmawati (2012), serta Nel Arianty (2015).

Berdasarkan hasil pengujian hipotesis kedua, diperoleh nilai koefisien beta sebesar 0,155 dengan signifikansi sebesar 0,008. Nilai koefisien beta yang 
memiliki arah positif serta nilai signifikansi yang lebih kecil dari tingkat probabilitas 0,05 mengartikan bahwa $\mathrm{H}_{2}$ diterima. Hasil dari pengujian ini adalah budaya organisasi berpengaruh positif dan signifikan terhadap prestasi kerja karyawan. Artinya, apabila budaya organisasi yang diterapkan Hotel Jhony Legian baik, maka prestasi kerja karyawan akan semakin meningkat. Sebaliknya, jika budaya organisasi tidak baik maka prestasi kerja karyawan akan semakin menurun.

Hasil penelitian ini memperkuat beberapa penelitian sebelumnya yang telah membuktikan bahwa budaya organisasi berpengaruh positif dan signifikan terhadap prestasi kerja karyawan seperti yang dilakukan Putra (2013) yang menyimpulkan bahwa dengan budaya perusahaan yang semakin baik berarti akan mampu meningkatkan prestasi kerja karyawan. Begitu juga penelitian yang dilakukan Mamuaja (2016), Shinta (2016), Moh. Fanani (2009), serta Riyan Putra (2013).

Berdasarkan hasil pengujian hipotesis ketiga, diperoleh nilai koefisien beta sebesar 0,133 dengan signifikansi sebesar 0,002. Nilai koefisien beta yang memiliki arah positif serta nilai signifikansi yang lebih kecil dari tingkat probabilitas 0,05 mengartikan bahwa $\mathrm{H}_{3}$ diterima. Hasil dari pengujian ini adalah pengembangan karir berpengaruh positif dan signifikan terhadap prestasi kerja karyawan. Artinya, apabila adanya pengembangan karir yang baik di Hotel Jhony Legian baik, maka prestasi kerja karyawan akan semakin meningkat. Sebaliknya, jika tidak adanya pengembangan karir yang baik maka prestasi kerja karyawan akan semakin menurun. 
Hasil penelitian ini memperkuat beberapa penelitian sebelumnya yang telah membuktikan bahwa pengembangan karir berpengaruh positif dan signifikan terhadap prestasi kerja karyawan seperti yang dilakukan Nurhasanah (2017) yang menyimpulkan bahwa jika pengembangan karir yang diberikan perusahaan baik maka akan memberikan dampak positif terhadap prestasi kerja karyawan. Begitu juga penelitian yang dilakukan Salama (2017), Luvy Chintya (2012), Harjanti (2017), serta Deawati (2010).

Berdasarkan hasil pengujian hipotesis keempat, diperoleh nilai koefisien beta sebesar 0,165 dengan signifikansi sebesar 0,003. Nilai koefisien beta yang memiliki arah positif serta nilai signifikansi yang lebih kecil dari tingkat probabilitas 0,05 mengartikan bahwa $\mathrm{H}_{4}$ diterima. Hasil dari pengujian ini adalah kepuasan kerja berpengaruh positif dan signifikan terhadap prestasi kerja karyawan. Artinya, apabila para karyawan Hotel Jhony Legian memiliki tingkat kepuasan kerja yang baik, maka prestasi kerja karyawan akan semakin meningkat. Sebaliknya, jika para karyawan tidak memiliki tingkat kepuasan kerja yang baik maka prestasi kerja karyawan akan semakin menurun.

Hasil penelitian ini memperkuat beberapa penelitian sebelumnya yang telah membuktikan bahwa kepuasan kerja berpengaruh positif dan signifikan terhadap prestasi kerja karyawan seperti yang dilakukan Rina (2011) yang menyimpulkan bahwa tingkat kepuasan kerja yang tinggi akan mempengaruhi prestasi karyawan di perusahaan. Begitu juga penelitian yang dilakukan Charitin Devi (2012), Ilham Anshari (2013), Agil Winedhar (2016), serta Supriyanto (2016). 
Hasil penelitian ini memberikan sebuah implikasi kepada hotel jhony legian mengenai bagaimana pentingnya kompensasi, budaya organisasi, pengembangan karir dan kepuasan kerja dapat mempengaruhi prestasi kerja pada karyawan Hotel Jhony Legian. Hasil yang diperoleh dari penelitian ini menunjukan hubungan secara langsung antar variable, salah satunya adalah kompensasi terhadap prestasi kerja karyawan. Hal ini menunjukan bahwa semakin besar kompensasi yang diterima oleh pegawai maka semakin baik prestasi kerja karyawan pada Hotel Jhony Legian, maka akan berdampak baik juga bagi kepuasan kerja karyawan dari Hotel Jhony Legian, selanjutnya terdapat hubungan langsung antara variabel pengembangan karir terhadap prestasi kerja karyawan, hal ini dapat diartikan bahwa semakin baik pengembangan karir yang diberikan oleh perusahaan maka akan semakin meningkat prestasi kerja karyawan. Selain itu, terdapat juga pengaruh langsung pada variabel budaya organisasi terhadap prestasi kerja karyawan. Implikasi penelitian ini dapat menggambarkan bahwa kompensasi, budaya organisasi, pengembangan karir dan kepuasan kerja yang baik sangat memengaruhi Prestasi Kerja Karyawan pada Hotel Jhony Legian.

Penelitian ini telah diusahakan dan dilaksanakan sesuai dengan prosedur ilmiah, namun demikian masih memiliki keterbatasan yaitu: faktor-faktor yang mempengaruhi Prestasi Kerja Karyawan dalam penelitian ini hanya terdiri dari kompensasi, budaya organisasi, pengembangan karir dan kepuasan kerja, sedangkan masih banyak factor lain yang mempengaruhi prestasi kerja karyawan. Adanya keterbatasan penelitian dengan menggunakan kuesioner yaitu terkadang 
I Made Dwika Pradnyana, Pengaruh Kompensasi,Budaya...

jawaban yang diberikan oleh responden tidak menunjukkan keadaan yang sebenarnya.

\section{SIMPULAN}

Kompensasi berpengaruh secara positif dan signifikan terhadap prestasi kerja karyawan. Hasil ini menunjukkan bahwa apabila kompensasi yang diberikan perusahaan kepada para karyawan Hotel Jhony Legian berada dalam tingkat yang baik, maka prestasi kerja karyawan akan semakin meningkat. Sebaliknya, jika kompensasi dinilai tidak baik maka prestasi kerja karyawan akan semakin menurun. Budaya organisasi berpengaruh secara positif dan signifikan terhadap prestasi kerja karyawan. Hasil ini menunjukkan bahwa apabila budaya organisasi yang diterapkan Hotel Jhony Legian baik, maka prestasi kerja karyawan akan semakin meningkat. Sebaliknya, jika budaya organisasi tidak baik maka prestasi kerja karyawan akan semakin menurun.

Pengembangan karir berpengaruh secara positif dan signifikan terhadap prestasi kerja karyawan. Hasil ini menunjukkan bahwa apabila adanya pengembangan karir yang baik di Hotel Jhony Legian baik, maka prestasi kerja karyawan akan semakin meningkat. Sebaliknya, jika tidak adanya pengembangan karir yang baik maka prestasi kerja karyawan akan semakin menurun. Kepuasan kerja berpengaruh secara positif dan signifikan terhadap prestasi kerja karyawan. Hasil ini menunjukkan bahwa apabila para karyawan Hotel Jhony Legian memiliki tingkat kepuasan kerja yang baik, maka prestasi kerja karyawan akan semakin meningkat. Sebaliknya, jika para karyawan tidak memiliki tingkat kepuasan kerja yang baik maka prestasi kerja karyawan akan semakin menurun. 
Gaji yang diterima oleh karyawan hendaknya diatur secara benar dan adil agar sumber daya manusia perusahaan memberikan timbal balik yang positif khususnya dalam hal prestasi kerja. Contohnya setiap bulan karyawan diberikan gaji sesuai dengan kontrak kerja dan manager tidak boleh terlambat memberikan gaji agar para karyawan tidak mengeluh.

Pelayanan yang diberikan seharusnya mengikuti prosedur yang telah ditetapkan agar sumber daya manusia memiliki landasan yang tepat dalam melakukan pekerjaan masing-masing sehingga terjadi peningkatan dalam prestasi kerja. Contohnya setiap ada pengunjung pihak hotel memberikan pelayanan sesuai dengan SOP dengan diawasi langsung oleh atasan.

Program pelatihan untuk meningkatkan kemampuan dalam melaksanakan tugas seharusnya rutin diadakan oleh perusahaan agar sumber daya manusia yang ingin mengembangkan karirnya perlu memiliki motivasi untuk melampaui standar kinerja yang ditentukan agar penilaian kinerjanya terlihat baik serta adanya peningkatan prestasi kerja. Contohnya para karyawan setidaknya 3 bulan atau 6 bulan sekali diberikan pelatihan-pelatihan yang khusus oleh pihak atasan agar prestasi kerja karyawan meningkat. Perusahaan memberikan kesempatan promosi untuk mengembangkan karir sebab karyawan yang memiliki tingkat kepuasan kerja yang tinggi akan menghasilkan prestasi kerja yang lebih baik. Contohnya sebaiknya pihak perusahaan lebih banyak memberi promosi kepada karyawan agar para karyawan merasakan hubungan yang baik dengan perusahaan dan bisa terjadi peningkatan kinerja. Karyawan seharusnya memiliki sikap kesadaran yang tinggi terhadap perusahaan agar lebih menunjukkan rasa tanggung jawab kepada 
perusahaan. Contohnya setiap karyawan hendaknya memiliki rasa takut atas tanggung jawab melaksanakan tugas yang diberikan agar kecil kemungkinan terjadi kesalahan dalam melakukan pekerjaan.

\section{REFERENSI}

Ardana, Komang, NiWayan Mujiati, dan I Wayan MudiarthaUtama. (2013) .Manajemen Sumber Daya Manusia.Yogyakarta;Graha Ilmu.Sugiyono.

Cropanzano, R., et al. (2000). Using social exchange theory to distinguish procedural from interactional justice. Group and Organization Management. Vol 27 No 3. 324-351.

Haar, J. M. (2014). Challenge and hindrance stressors in New Zealand: exploring social exchange theory outcomes. International Journal of Human Resource Management. Vol. 17 No. 11. Pp: 1942-1950.

Hamdani, Muhammad. (2013). Analisis pengaruh iklim organisasi, komitmen dan budaya organisasi terhadap prestasi kerja dosen Akademi Pariwisata Medan. Tesis. Universitas Sumatera Utara. Sekolah Pascasarjana.

Hasibuan, Malayu S.P. (2013). Manajemen Sumber Daya Manusia Edisi Revisi. Jakarta: Bumi Aksara. Herman, Sofyandi. 2008. Manajemen Sumber Daya Manusia. Yogyakarta : Graha Ilmu.

Herman, Sofyandi. (2008). Manajemen Sumber Daya Manusia. Yogyakarta : Graha Ilmu.

Korir, I. dan Kipkebut, D. (2016). The effect of reward management on employees commitment in the Universities in Nakuru County-Kenya. Journal of Human Resource Management. Vol. 4 No. 4. pp. 37-48.

Kotler, Amstrong. (2014). Dasar-dasar Pemasaran. Edisi Bahasa Indonesia. Jakarta : PT. Prehallindo

Mamuaja, A.B., Tumbel, A., \& Sepang, J. L. (2016). Pengaruh budaya organisasi, lingkungan kerja dan disiplin kerja terhadap prestasi kerja karyawan PT. Daya Anugrah Mandiri Cabang Airmadidi. Jurnal Berkala Ilmiah Efisiensi. Vol 16 No. 01. 109-119.

Martoyo, Susilo. (2014). Manajemen Sumber Daya Manusia. Yogyakarta: BPFE.

McShane, Steven L. and Mary Ann Von Glinow. (2013). Organizational Behavior. Fourth Edition. New York: McGraw-Hill. 
Nurhasanah, V. M., Hidayat, A. R., \& Irfani, A. (2016). Pengaruh Pengembangan Karir Terhadap Prestasi Kerja Karyawan pada Bank BJB Syariah Kantor Cabang Braga. Prosiding Keuangan dan Perbankan Syariah. Vol 3 No 1. 209-215

Permadi, I Made Yudi. (2017). Pengaruh Kompensasi, Budaya Organisasi Dan Lingkungan Kerja Terhadap Kepuasan Kerja Karyawan. E-Jurnal Manajemen Unud, 6 (1):521-549

Putra, R. S. (2013). Pengaruh budaya perusahaan terhadap prestasi kerja karyawan PT. Pembangkitan Jawa- Bali Surabaya unit Pelayanan Pemeliharaan. JMK . Vol. 1 5, No. 2. 131-140

Ratna, E. D., Hadi, S.P., \& Suryoko, S. (2014). Pengaruh kepemimpinan dan kompensasi terhadap prestasi kerja karyawan PT. Pelindo III Cabang Semarang. Diponegoro Journal Of Social And Politic. Pp 1-7.

Reffiany. (2018). Pengaruh budaya organisasi, motivasi kerja dan gaya kepemimpinan yang diinteraksikan dengan pengendalian sikap individu (locus of control) terhadap prestasi kerja pada Pusat Penelitian Kelapa Sawit (PPKS) Medan. Tesis. Universitas Sumatera Utara. Sekolah Pascasarjana

Robbins, S.P., \& Judge. (2013). Perilaku Organisasi Buku 2. Jakarta : Salemba Empat.

Salama, Hasmin, \& Natsir, M. (2017). Pengaruh pelatihan, motivasi kerjadan pengembangan karir terhadap prestasi kerja pegawai pada satuan Polisi Pamong Praja Kabupaten Soppeng. Jurnal Mirai Management. Volume 2 Nomor 1. 164-174.

Setiawan, G. A. (2016). Pengaruh motivasi kerja dan kompensasi terhadap prestasi kerja karyawan PT. Sun Star Motor cabang Negara tahun 2016. Jurnal Program Studi Pendidikan Ekonomi. Vol 8 Nomor 3. 1-10

Wahyuni, D., Hamidah Nayati Utami, Ika Ruhana. (2014). Pengaruh Pengembangan Karirterhadap Prestasi Kerja Karyawan PT. Astra Internasional, Tbk Daihatsu Malang.Fakultas Ilmu Administrasi Universitas Brawijaya Vol.8, No 1. 